\title{
Sekuen Penyandi 18S Ribosomal RNA dan Ubiquitin pada Pandanus sp. Asal Riau \\ (Sequences Encoding 18S Ribosomal RNA and Ubiquitin on Pandanus sp. from Riau)
}

\author{
Dewi Indriyani Roslim ${ }^{1) *}$, Nurin Nuryani1), Herman ${ }^{1)}$ \\ 1)Laboratorium Genetika, Jurusan Biologi, Fakultas Matematika dan IImu Pengetahuan \\ Alam, Universitas Riau, Indonesia, Kampus Bina Widya, Jl. HR Soebrantas Km 12.5, \\ Panam, Pekanbaru 28293, Riau, Indonesia \\ *Email korespondensi: dewiindriyaniroslim@gmail.com
}

Diterima 26 Januari 2018, diterima untuk dipublikasikan 23 Februari 2018

\begin{abstract}
Abstrak
Gen penyandi $18 S$ ribosomal RNA (18S rRNA) dan ubiquitin merupakan anggota dari housekeeping genes yang sering digunakan sebagai kontrol internal pada analisis ekspresi. Penelitian bertujuan mengisolasi kedua gen tersebut pada tanaman Pandanus sp asal Riau. Metode penelitian meliputi isolasi DNA total, elektroforesis, PCR, purifikasi gel, sekuensing, dan analisis data sekuen DNA menggunakan program BioEdit version 7.0.0, BLASTn, dan MEGA6. Sekuen DNA penyandi 18S rRNA (420 bp) dan ubiquitin (493 bp) telah diperoleh. Sekuen 18S rRNA Pandanus sp memiliki kemiripan sebesar 99\% dengan beberapa spesies Pandanus. Sekuen ubiquitin Pandanus sp memiliki kemiripan sebesar 87\%-89\% dengan sekuen ubiquitin dari beberapa tanaman dan alga hijau. Dendrogram yang diturunkan dari kedua sekuen juga mendukung hasil tersebut bahwa sekuen $18 S$ rRNA dari Pandanus sp. membentuk satu kelompok dengan sesama sekuen 18S rRNA, begitu pula dengan sekuen ubiquitin Pandanus sp. membentuk satu kelompok dengan sesama sekuen ubiquitin. Kedua gen berpotensi dijadikan kontrol internal setelah dilakukan validasi.

Kata kunci: RNA ribosom 18S, housekeeping gene, Pandanus sp., Riau, ubiquitin.
\end{abstract}

\section{Abstrak}

This research aimed to isolate genes encoding $18 S$ rRNA and ubiquitin in Pandanus sp. from Riau. The research method included total DNA extraction, polymerase chain reaction, electrophoresis, gel purification, sequencing, and DNA sequence analysis using BioEdit version 7.0.0, BLASTn, and MEGA6 programs. Sequences encoding $18 S$ rRNA (420 bp) and ubiquitin (493 bp) had been obtained. The BLASTn analysis showed that $18 S$ rRNA of Pandanus sp. had $99 \%$ similarity to some species of Pandanus. Ubiquitin sequence in Pandanus sp. had $87 \%-89 \%$ similarity to ubiquitin sequences of some plants and green algae. Dendrograms generated from both sequences also supported the results that $18 S$ rRNA sequence of Pandanus sp. was the same group as $18 S$ rRNA on Pandanus genus. Similarly, ubiquitin sequence of Pandanus sp was the same cluster as other plants. Both genes were potentially used as internal control in gene expression studies after their validation.

Keywords: $18 S$ ribosomal RNA, housekeeping gene, Pandanus sp., Riau, ubiquitin. 


\section{PENDAHULUAN}

Pandanus sp. merupakan salah satu tumbuhan yang tumbuh di Danau Kajuik yang merupakan salah satu danau paparan banjir yang berlokasi di Provinsi Riau, Indonesia (Elvyra dan Yus 2010; Roslim 2016). Danau paparan banjir adalah daerah dataran rendah yang tergenang air akibat luapan air sungai pada musim hujan lalu genangan tersebut membentuk danau. Pandanus $\mathrm{sp}$ bersama-sama dengan tumbuhan lain yang tumbuh di ekosistem danau tersebut, seperti Syzygium sp (Roslim et al. 2016a), Calamus $\mathrm{sp}$ dan Gluta renghas (Roslim 2016), Elaeocarpus floribundus (Roslim et al. 2016b), dan Putat (Planchonia valida) (Elvyra dan Yus 2010), memiliki peran yang sangat penting bagi kelangsungan hidup di ekosistem tersebut. Mereka berperan penting dalam menyediakan tempat berlindung, memijah, dan mengasuh anak ikan dan hewan lainnya, menyediakan nutrisi bagi fauna di ekosistem tersebut, dan menahan tanah di tepi danau agar tidak tergerus ke dalam danau (Pease et al. 2006; Zeug \& Winemiler 2008). Fauna yang hidup di ekosistem tersebut diantaranya meliputi ikan, udang, burung, serangga, dan hewan air lainnya. Ikan-ikan yang bermigrasi ke Danau Kajuik salah satunya adalah ikan selais yang merupakan ikan endemik Riau (Elvyra dan Yus 2010).

Pandanus sp. dapat tumbuh baik pada kondisi tergenang air pada musim hujan maupun kondisi kering pada musim kemarau. Hal ini mengindikasikan bahwa tanaman ini menyimpan berbagai gen yang terkait dengan toleransinya terhadap cekaman penggenangan. Untuk mempelajari ekspresi dari gen-gen tersebut diperlukan satu atau beberapa gen referensi sebagai kontrol internal. Gen penyandi $18 \mathrm{~S}$ ribosomal RNA dan ubiquitin merupakan gen referensi yang sering digunakan sebagai kontrol internal pada analisis ekspresi gen. Gen referensi merupakan gen yang ekspresinya stabil, tidak diinduksi oleh perlakuan tertentu, dan melimpah pada semua jaringan dan tahapan perkembangan organisme eukariot (Thellin et al. 1999). Selain 18S rRNA dan ubiquitin, beberapa yang termasuk kelompok gen referensi yang telah berhasil diidentifikasi dari berbagai tanaman adalah gen penyandi glyceraldehyde-3-phosphate dehydrogenase (GAPDH), faktor inisiasi transkripsi (TIF), aktin (Act), cyclophilin $(C A C)$, tubulin (TUB), faktor elongasi translasi (EF1a) (Jain et al. 2006; Caldana et al. 2007), dan 25S rRNA (Jain et al. 2006).

Gen 18S rRNA menyandikan ribosomal RNA berukuran 18S yang merupakan penyusun sub unit kecil ribosom eukariot dan berperan penting dalam pengenalan dan hibridisasi mRNA yang akan ditranslasikan di ribosom (Dresios et al. 2006). Isolasi dan validasi gen 18S rRNA sebagai gen referensi sudah dilakukan pada berbagai tanaman, seperti pada berbagai tanaman Chenopodium album (Aman et al. 2017), padi (Jain et al. 2006), dan tembakau (Nicot et al. 2005).

Gen penyandi ubiquitin yang merupakan anggota dari famili protein regulator pada sel eukariot telah diisolasi dan divalidasi sebagai gen referensi pada beberapan tumbuhan, seperti Brassica juncea (Chandna et al. 2012) and Solanum melongena (Gantasala et al. 2013).

Informasi mengenai gen referensi pada Pandanus sp. asal Riau sampai saat ini belum tersedia di database GenBank dan belum pernah diteliti. Oleh karena itu, sebagai langkah awal pada penelitian ini akan dilakukan isolasi 
gen penyandi 18S rRNA dan ubiquitin dari tumbuhan Pandanus $\mathrm{sp}$ asal Riau yang nantinya gen referensi tersebut dapat digunakan sebagai kontrol internal pada analisis ekspresi gen-gen terkait cekaman penggenangan dan melengkapi database di GenBank.

\section{METODE \\ Bahan Penelitian}

Bahan tanaman yang digunakan pada penelitian ini adalah daun segar Pandanus sp. yang diambil dari Danau Kajuik. Danau tersebut terletak di Kecamatan Langgam, Kabupaten Pelalawan, Provinsi Riau, Indonesia. Pasangan primer yang digunakan untuk ampliflikasi gen 18S rRNA adalah forward 5'-CGC GCA AAT TAC CCA ATC CTG ACA-3' dan reverse 5'TCC CGA AGG CCA ACG TAA ATA GGA-3' (Gantasala et al. 2013). Pasangan primer untuk amplifikasi gen ubiquitin adalah forward 5'-GCY AAR ATH CAR GAY AAG GA-3' dan reverse 5'-TGD AGD GTK GAY TCC TTC T-3' yang dirancang berdasarkan daerah terkonservasi dari gen tersebut.

\section{Isolasi DNA Total}

Sebanyak $500 \mathrm{mg}$ daun segar dipotong kecil-kecil kemudian digerus menggunakan mortar dan pestel di dalam Nitrogren cair. Setelah itu, bubuk daun dimasukkan ke dalam tabung $1.5 \mathrm{ml}$ dan selanjutnya dilakukan ekstraksi DNA menggunakan DNeasy plant mini kit (Qiagen).

\section{Polymerase Chain Reaction (PCR)}

Proses PCR dilakukan dalam volume reaksi sebanyak 50 ul dengan komponen sebagai berikut: $1 \mathrm{X}$ buffer PCR (plus $\mathrm{Mg}^{2+}$ ), $0.1 \mathrm{mM}$ dNTPs, $0.2 \mu \mathrm{M}$ primer forward, 0.2 $\mu \mathrm{M}$ primer reverse, $1 \mathrm{U}$ enzim Dream Taq DNA polymerase (Thermo Scientific), dan 50 ng DNA total, dan akuabidestilata. Kondisi PCR adalah sebagai berikut: prePCR selama 5 menit pada $94^{\circ} \mathrm{C}$ sebanyak 1 siklus; denaturasi selama 45 detik pada $94{ }^{\circ} \mathrm{C}$, penempelan primer selama 45 detik pada $55^{\circ} \mathrm{C}$ untuk pasangan primer 18S rRNA dan $51.2{ }^{\circ} \mathrm{C}$ untuk pasangan primer ubiquitin, dan pemanjangan primer selama 1 menit pada $72{ }^{\circ} \mathrm{C}$, ketiga tahap tersebut diulang sebanyak 35 siklus. Proses PCR diakhiri dengan tahapan postPCR selama 10 menit pada $72^{\circ} \mathrm{C}$.

\section{Elektroforesis}

Molekul DNA total dan produk PCR dimigrasikan dengan elektroforesis pada $1.2 \%$ gel agarose untuk menentukan kualitas dan kuantitasnya. Buffer elektroforesis yang digunakan adalah larutan $1 \mathrm{X}$ TBE $(89 \mathrm{mM}$ Tris, $89 \mathrm{mM}$ boric acid, 2 mM EDTA, pH 8.0). Elektroforesis dilakukan pada tegangan 75 volt selama 20 menit. Setelah itu, pita DNA pada gel diwarnai dengan cara merendam gel di dalam laruta 5 $\mu \mathrm{g} / \mathrm{ml}$ ethidium bromide. Visualisasi pita DNA yang sudah diwarnai tersebut dilakukan menggunakan lampu UV transilluminator (WiseUV WUV-M20, Daihan Scientific) dan pita yang tampak difoto menggunakan kamera digital (Olympus SP-500 UZ).

\section{Purifkasi Gel dan Sekuensing}

Tabung PCR yang berisi produk PCR kemudian tutup rapat menggunakan parafilm lalu dikirim ke ke $1^{\text {st }}$ Base Malaysia melalui PT Genetika Science Indonesia. untuk dilakukan purifikasi gel dan sekuensing. Sekuensing dilakukan dua arah menggunakan pasangan primer saat PCR.

\section{Analisis Data Sekuen DNA}

Sekuen DNA yang diperoleh kemudian diolah menggunakan program progam BLASTn yang 
tersedia di (Basic Local Alignment Search Tool) at http://www.ncbi. nlm.nih.gov/BLAST (Altschul et al. 1997) dan MEGA6 (Build\#: 6140226) (Molecular Evolutionary Genetics Analysis) (Tamura et al. 2013). Hasil analisis ditampilkan dalam bentuk gambar, tabel, dan dendrogram. Dendrogram dikonstruksi menggunakan Kimura 2-parameter model dan UPGMA (Unweighted Pair Group Method with Arithmetic mean) bootstrap 1000 kali.

\section{HASIL DAN PEMBAHASAN}

Sekuen DNA parsial sepanjang 420 bp untuk gen $18 S$ rRNA dan 493 bp untuk gen ubiquitin telah diperoleh. Sekuen tersebut telah didaftarkan dan telah mendapatkan nomor accession sebagai berikut: KY751912 untuk gen penyandi 18S rRNA parsial KY751913 dan untuk gen penyandi ubiquitin parsial (Gambar 1).

Hasil analisis BLASTn terhadap sekuen 18S rRNA menunjukkan bahwa tidak seluruh sekuen 18S rRNA dari Pandanus sp tersejajarkan dengan database di GenBank yang ditunjukkan dengan nilai query cover sebesar $99 \%$. Sekuen 18S rRNA dari Pandanus sp memiliki kemiripan dengan beberapa spesies dari genus Pandanus dengan nilai identity sebesar $99 \%$. Sementara itu, hasil analisis BLASTn terhadap sekuen ubiquitin menunjukkan bahwa seluruh sekuen ubiquitin dari Pandanus sp terpakai dalam analisis BLASTn yang ditunjukkan dengan nilai query cover sebesar $100 \%$. Sekuen ubiquitin dari Pandanus sp memiliki kesamaan dengan sekuen ubiquitin dari beberapa tanaman dan alga yang ditunjukkan dengan nilai identity sekitar $87 \%-89 \%$ (Tabel 1). Hasil anaisis BLASTn dengan nilai query cover dan identity yang tinggi pada kedua sekuen yang diteliti menunjukkan bahwa sekuen DNA yang diperoleh pada penelitian ini memang benar merupakan bagian dari gen penyandi $18 S$ rRNA dan ubiquitin.

Dendrogram yang diturunkan berdasarkan kedua sekuen tersebut menunjukkan bahwa sekuen DNA penyandi $18 \mathrm{~S}$ rRNA dari Pandanus $\mathrm{sp}$ asal Riau membentuk satu kelompok dengan sesama gen penyandi 18S rRNA dari genus Pandanus. Begitu pula dengan sekuen DNA penyandi ubiquitin dari Pandanus sp asal Riau membentuk satu kelompok dengan sesama sekuen DNA penyandi ubiquitin dari beberapa tanaman dan alga (Gambar 2). Dendrogram tersebut memperkuat bahwa sekuen DNA dari Pandanus sp asal Riau yang diperoleh pada penelitian ini adalah benar bagian dari sekuen DNA penyandi 18S rRNA dan ubikuitin.

Analisis ekspresi gen membutuhkan kontrol internal untuk memastikan bahwa besar kecil ekspresi gen target bukan karena human error atau pipetting error. Gen yang umum dijadikan sebagai kontrol internal adalah gen referensi yang telah divalidasi (Volkov et al. 2003; Nicot et al. 2005; Jain et al. 2006; Banaras et al. 2012; Chandna et al. 2012; Gantasala et al. 2013). Isolasi gen-gen referensi dari Pandanus sp asal Riau belum pernah dilaporkan.

Pada penelitian ini, telah berhasil diisolasi sekuen DNA penyandi $18 \mathrm{~S}$ rRNA dan ubiquitin dari Pandanus $\mathrm{sp}$ asal Riau. Besarnya nilai identity antara sekuen 18S rRNA dari Pandanus sp asal Riau dengan beberapa aksesi dari genus Pandanus tidak mencapai $100 \%$ dan ini mengindikasikan bahwa sekuen yang diperoleh pada penelitian ini adalah baru dan belum pernah dilaporkan sebelumnya. 


\begin{tabular}{l}
\hline > KY751912 | Pandanus sp asal Riau, sekuen gen 18S \\
rRNA parsial \\
TCGCGCAAATACCCAATCCTGACACGGGGAGGTAGTGACAATAAATAAC \\
AATACCGGGTCCTAGAGTCGGTAATTGGAATGATACAATCTAAATCC \\
CTTAACGAGGATCCATTGGAGGGCAAGTCTGGTGCCAGCAGCCGCGTAA \\
TTCCAGCTCCAATAGCGTATATTTAAGTTGCTGCAGTTAAAAAGCTCGTA \\
GTTGGACCTTGGGTGGGCCGGCCGTCCGCCTTCGGGTGCACCGGCG \\
TCTCGTCCCTTCTGCCGGCGATGCGCTCCTGGCCTTAACTGCGCCGGTC \\
GTGCCTCCGGCGCCGTACTTTGAAGAAATTAGAGTGCTCAAAGCAAGCC \\
TACGCTCTGCATACATTAGCATGGGATAACATCATAGGATTCGGTCCTA \\
TTTACGTTGGCCTTCGGGAA \\
\hline >KY751913 | PandanUS sP asal Riau, sekuen gen \\
ubiquitin parsial \\
CTGGTCCTCCGCCTTCGAGGTGGCATGCAAATCTTCGTCAAGACTTTGAC \\
AGGCAAGACCATCACCCTCGAGGTGGAGTCTTCCGACACCATTGACAACG \\
TTAAGGCGAAGATCCAGGACAAGGAGGGCATCCCCCGGACCAGCAGCGT \\
CTCATCTTTGCTGGCAAGCAGCTCGAGGACGGGCGCACCCTCGCCGACTA \\
TAACATCCAGAAGGAATCCACCCTCCAACTGGTCCTCCGCCTTCGAGGTG \\
GCATGCAAATCTTCGTCAAGACTCTGACAGGCAAGACCATCACCCTCGAG \\
GTGGAGTCTTCCGACACCATTGACAACGTTAAGGCGAAGATCCAGGACAA \\
GGAGGGCATCCCCCCGACCAGCAGCGTCTCATCTTTGCTGGCAAGCAGC \\
TCGAGGACGGGCGCACCCTCGCCGACTATAACATCCAGAAGGAATCCACC \\
CTACAACTGGTCCTGGGCCTTCGAGGTGGCATGCAAATCTTCG \\
\hline
\end{tabular}

Gambar 1. Sekuen gen penyandi 18S rRNA (atas) dan ubiquitin (atas) pada Pandanus sp asal Riau.

Tabel 1. Hasil analisis BLAST terhadap sekuen gen penyandi 18S rRNA dan ubiquitin parsial pada Pandanus sp asal Riau.

\begin{tabular}{lcccccc}
\hline Deskripsi & $\begin{array}{c}\text { Skor } \\
\text { Maksimal }\end{array}$ & $\begin{array}{c}\text { Skor } \\
\text { Total }\end{array}$ & $\begin{array}{c}\text { Query } \\
\text { cover }\end{array}$ & E-value & $\begin{array}{c}\text { Nilai } \\
\text { Identity }\end{array}$ & Aksesi \\
\hline Gen 18S rRNA & & & & & & \\
\hline Pandanus baptistii & 733 & 733 & $99 \%$ & 0.0 & $99 \%$ & KF298360.1 \\
Pandanus cf. dubius & 733 & 733 & $99 \%$ & 0.0 & $99 \%$ & KF298359.1 \\
Pandanus furcatus & 733 & 733 & $99 \%$ & 0.0 & $99 \%$ & KF298358.1 \\
Pandanus labyrinthicus & 733 & 733 & $99 \%$ & 0.0 & $99 \%$ & KF298357.1 \\
Pandanus pacificus & 733 & 733 & $99 \%$ & 0.0 & $99 \%$ & KF298355.1 \\
Pandanus stenophyllus & 733 & 733 & $99 \%$ & 0.0 & $99 \%$ & KF298353.1 \\
Pandanus tectorius & 733 & 733 & $99 \%$ & 0.0 & $99 \%$ & KF298352.1 \\
\hline Gen Ubiquitin & & & & & & \\
Aegilops tauschii & 654 & 3723 & $100 \%$ & 0.0 & $89 \%$ & XM_020309243.1 \\
Micromonas sp & 641 & 3192 & $100 \%$ & $5 \mathrm{e}-180$ & $89 \%$ & XM_002508129.1 \\
Oryza brachyantha & 632 & 3493 & $100 \%$ & $3 \mathrm{e}-177$ & $88 \%$ & XM_006646848.2 \\
Panicum virgatum & 616 & 3608 & $100 \%$ & $2 \mathrm{e}-172$ & $88 \%$ & HM209468.1 \\
Oryza sativa & 614 & 3521 & $100 \%$ & $7 \mathrm{e}-172$ & $88 \%$ & GQ848039.1 \\
Micromonas pusilla & 614 & 3019 & $100 \%$ & $7 \mathrm{e}-172$ & $88 \%$ & XM_003061910.1 \\
Saccharum hybrid & 605 & 2873 & $100 \%$ & $4 \mathrm{e}-169$ & $88 \%$ & AF093505.1 \\
Brachypodium distachyon & 603 & 2882 & $100 \%$ & $1 \mathrm{e}-168$ & $87 \%$ & NM_001317880.1 \\
$\begin{array}{l}\text { Monoraphidium neglectum } \\
\text { Triticum aestivum }\end{array}$ & 598 & 2862 & $100 \%$ & $5 \mathrm{e}-167$ & $87 \%$ & XM_014044992.1 \\
\hline
\end{tabular}




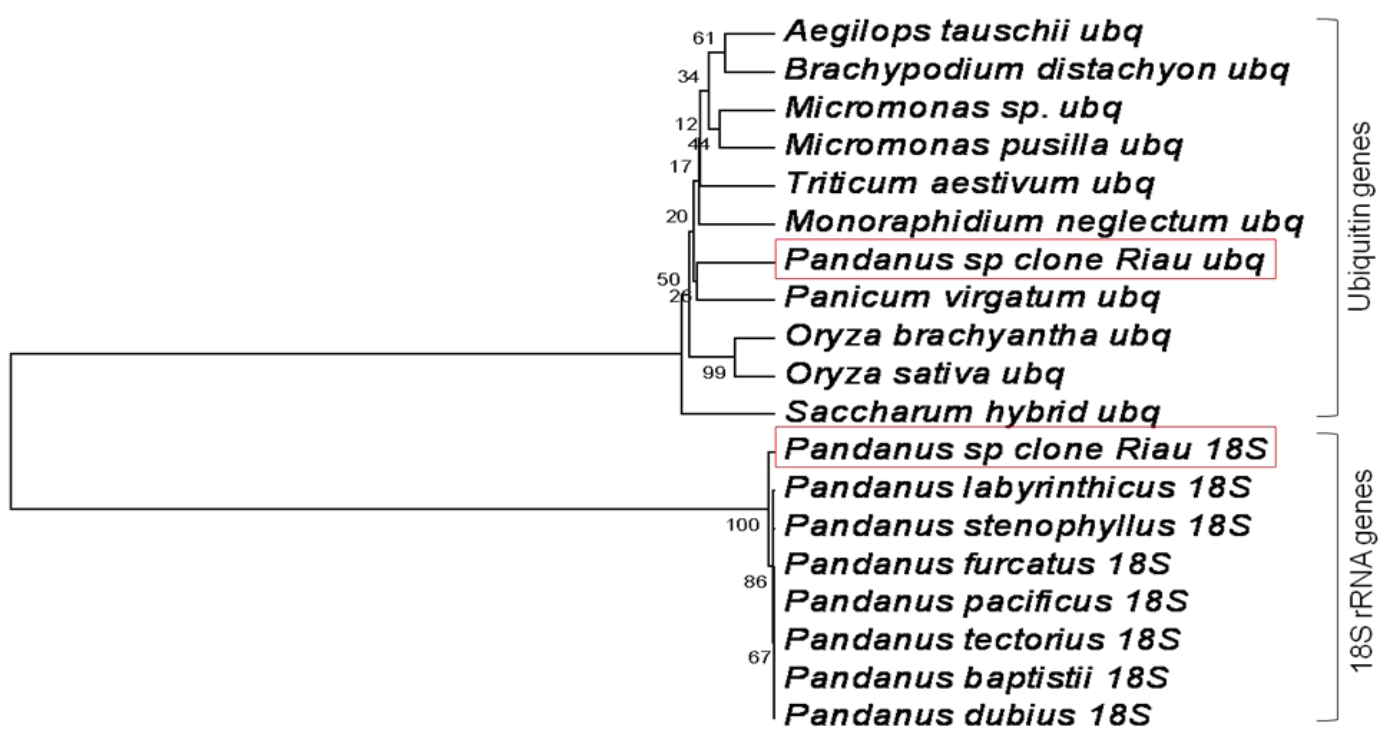

Gambar 2. Dendrogram yang dikonstruksi berdasarkan sekuen penyandi $18 \mathrm{~S}$ rRNA dan ubiquitin. Kalkulasi menggunakan Kimura 2-parameter model and UPGMA (Unweighted Pair Group Method with Arithmetic mean) dengan bootstrap 1000 kali.

Tidak ada satupun data sekuen DNA penyandi ubiquitin dari genus Pandanus yang muncul pada hasil analisis BLASTn. Hal tersebut mengindikasikan bahwa belum pernah ada laporan dan atau belum pernah didaftarkan pada database GenBank mengenai sekuen penyandi ubiquitin dari genus Pandanus. Dengan demikian ini adalah sekuen ubiquitin pertama yang pernah dilaporkan dari genus Pandanus.

Pada setiap organisme, tingkat kestabilan ekspresi dari housekeeping gene bervariasi. Oleh karena itu, sekuen yang diperoleh pada penelitian ini perlu divalidasi untuk keperluannya sebagai kontrol internal pada analisis ekspresi gen di Pandanus sp asal Riau. Aman et al. (2017) melaporkan bahwa sekuen penyandi 18S rRNA dan $\beta$-tubulin pada tanaman Chenopodium album adalah yang paling stabil ekspresinya dan telah divalidasi sehingga layak digunakan sebagai kontrol internal. Sementara itu,
Galeano et al. (2014) melaporkan bahwa gen ubiquitin dan EF1 alfa adalah yang paling stabil ekspresinya dan telah divalidasi sebagai kontrol internal pada tanaman Tectona grandis L.f.

\section{KESIMPULAN}

Pada penelitian ini telah diperoleh sekuen DNA parsial penyandi $18 \mathrm{~S}$ ribosomal RNA berukuran 420 bp dan ubiquitin berukuran 493 bp. Sekuen 18S rRNA dari Pandanus sp memiliki kemiripan sebesar 99\% dengan beberapa spesies Pandanus. Sekuen ubiquitin dari Pandanus sp memiliki kemiripan sebesar $87 \%$ $89 \%$ dengan sekuen ubiquitin dari beberapa tanaman dan alga hijau. Dendrogram yang diturunkan dari kedua sekuen juga mendukung hasil tersebut bahwa sekuen 18S rRNA dari Pandanus sp membentuk satu kelompok dengan sesama sekuen 18S rRNA dari genus Pandanus, begitu pula dengan sekuen ubiquitin 
dari Pandanus sp membentuk satu kelompok dengan sesama sekuen ubiquitin lainnya. Kedua gen tersebut berpotensi sebagai kontrol internal pada analisis ekspresi gen pada Pandanus sp asal Riau setelah dilakukan validasi.

\section{UCAPAN TERIMA KASIH}

Penelitian ini dibiayai oleh Kementrian Riset, Teknologi, dan Pendidikan Tinggi, Republik Indonesia - Direktorat Jenderal Riset dan Pengabdian Kepada Masyarakat melalui Hibah Penelitian Dasar Unggulan Perguruan Tinggi tahun anggaran 2017 dengan nomor kontrak 489/UN.19.5.1.3/PP/2017. Terima kasih disampaikan kepada LPPM Universitas Riau yang telah menfasilitasi penelitian ini.

\section{DAFTAR PUSTAKA}

Altschul SF, Madden TL, Schaffer AA, Zhang J, Zhang Z, Miller W, Lipman DJ (1997) Gapped BLAST and PSI-BLAST: a new generation of protein database search programs. Nucleic Acid Res 25: 3389-3402.

Aman S, Haq NU, Ahmed S, Shakeel SN (2017) Identification and validations of reference genes for gene expression data normalization of Chenopodium album. Int $\mathrm{J}$ Agric Biol 19: 761-770.

Caldana C, Scheible WR, MuellerRoeber B, Ruzicic S (2007) A quantitative RT-PCR platform for high throughput expression profiling of 2500 rice transcription factors. Plant Methods 3:7 doi: 10.1186/1746-4811-3-7.

Chandna R, Augustine R, Bisht NC (2012) Evaluation of candidate reference genes for gene expression normalization in Brassica juncea using real time quantitative RT-PCR. PLoS
ONE $\quad 7(5): \quad$ e36918.

doi:10.1371/journal.

pone.0036918.

Dresios J, Chappell SA, Zhou W, Mauro VP (2006) An mRNArRNA base-pairing mechanism for translation initiation in eukaryotes. Nat Struct Mol Biol 13: 30-34.

Elvyra R, Yus Y (2010) Ikan Lais dan Sungai Paparan Banjir di Provinsi Riau. UR Press Pekanbaru, Pekanbaru.

Gantasala NP, Papolu PK, Thakur PK, Kamaraju D, Sreevathsa R, Rao U (2013) Selection and validation of reference genes for quantitative gene expression studies by real-time PCR in eggplant (Solanum melongena $\mathrm{L}$ ). BMC Research Notes 6:312.

Jain $M$, Nijhawan A, Tyagi AK, Khurana JP (2006) Validation of housekeeping genes as internal control for studying gene expression in rice by quantitative real-time PCR. Biochemical and Biophysical Research Communications 345: 646-651.

Nicot N, Hausman JF, Hoffmann L, Evers D (2005) Housekeeping gene selection for real-time RT-PCR normalization in potato during biotic and abiotic stress. J Exp Bot 56(421): 2907-2914.

Pease AA, Davis JJ, Edwards MS, Turner TF (2006) Habitat and resource use by larval and juvenile fishes in an arid-land river (Rio Grande, New Mexico). Freshwater Biology DOI:10.1111/j.13652427.2005.01506.x.

Roslim DI (2017) Pandan (Pandanus $\mathrm{sp})$, Rotan (Calamus sp), and Rengas (Gluta sp) from Kajuik Lake, Riau Province, Indonesia. Brazilian Archives 
of Biology and Technology 60: e17160419. [in press].

Roslim DI, Nurkhairani P, Herman, Elvyra R (2016a) Identification of durik-durik plant (Syzygium sp) using the psbA-trnH intergenic spacer and ITS regions. TPGM 3: 11-16.

Roslim DI, Khumairoh S, Herman (2016b) Confirmation of tuntun angin

(Elaeocarpus

floribundus) taxonomic status using matK and ITS sequences. Biosaintifika: Journal of Biology \& Biology Education 8(3), 392-399.

Tamura K, Stecher G, Peterson D, Filipski A, Kumar S (2013) MEGA6: molecular evolutionary genetics analysis version 6.0. Mol Biol Evol 30: 2725-2729. doi: $10.1093 / \mathrm{molbev} / \mathrm{mst} 197$

Thellin O, Zorzi W, Lakaye B, Borman BD, Coumans B,
Hennen G, Grisar T, Igout A, Heinen E (1999)

Housekeeping genes as internal standards: use and limits. J Biotechnol 75:291-295. Volkov RA, Panchuk II, Schoffl (2003) Heat-stressdependency and developmental modulation of gene expression: the potential of house-keeping genes as internal standards in mRNA expression pro®ling using realtime RT-PCR. J Exp Bot 54(391): 2343-2349. DOI: $10.1093 / \mathrm{jxb} / \mathrm{erg} 244$.

Zeug SC, Winemiller KO (2008) Relationships between hydrology, spatial heterogeneity, and fish recruitment dynamics in a temperate floodplain river. River Res Applic 24: 90-102. DOI: $\quad 10.1002 /$ rra.1061. 